\title{
Læring + mestring $=$ god helseøkonomi
}

Ulike typer lærings- og mestringstilbud er gode og kostnadseffektive tiltak for å sikre en mer likeverdig helsetjeneste.

\section{Una Stenberg}

Seniorforsker

Nasjonal kompetansetjeneste for læring og mestring innen helse, Oslo universitetssykehus

\section{Kari Hvinden}

Sykepleier og spesialrådgiver

Nasjonal kompetansetjeneste for læring og mestring innen helse, Oslo universitetssykehus

\section{André Vågan}

Seniorforsker

Nasjonal kompetansetjeneste for læring og mestring innen helse, Oslo universitetssykehus

\section{Maria Flink}

Sosionom og postdoktor

Karolinska Universitetssjukhuset

\section{Kari Fredriksen}

Leder og pedagog

Lærings- og mestringssenteret, Helse Stavanger

\section{Frode Gallefoss}

Lege og forskningssjef

Sørlandet sykehus

Opplæring

Pasientundervisning

Helseøkonomi

Læring og mestring

Evaluering 
Til tross for at stadig flere pasienter og pårørende har behov for forskjellige lærings- og mestringstilbud, er det fortsatt ganske tilfeldig hvem som får tilbud. Hva vet vi i dag om helseøkonomisk utbytte for helsetjenesten og dem som deltar i slike tilbud?

En systematisk gjennomgang av den internasjonale forskningslitteraturen viser at det å delta i ulike typer tilbud med mål om læring og mestring kan være svært effektivt for å kutte kostnader i helsetjenesten (1).

Som sosial- og helsepersonell er vi opptatte av at pasienter og pårørende skal få tilgang til skreddersydd kunnskap og ulike mestringsstrategier for å kunne ha et så godt liv som mulig, også de som har helseutfordringer.

I det kliniske arbeidet bidrar vi med å styrke pasientenes mestring, eller med å etablere mestringstilbud i virksomheten. Det kan vise seg å være svært nyttig, både for den enkelte pasienten eller de pårørende, men også i et ressurs- og kostnadsperspektiv.

\section{Tidligere forskning}

Av studiene som har unders $\varnothing \mathrm{kt}$ helse $\varnothing$ konomisk effekt eller utbytte, totalt 56 studier, viser mer enn 80 prosent, 46 studier, at det å delta i både individuelle og/eller gruppebaserte tilbud er svært effektivt for å kutte kostnader i helsetjenesten. Dette funnet var uavhengig av studiedesign og tidsperspektiv.

Personer som har deltatt i slike tilbud, har færre eller kortere sykehusinnleggelser, færre konsultasjoner på poliklinikken og hos fastlegen samt færre sykedager enn de som ikke deltar. I mange av studiene rapporteres det også om positive resultater på kvalitetsjusterte leveår (QALY) (se faktaboks). 
Selv om lite av denne forskningen er fra Norge, er resultatene overførbare til norske forhold. Resultatene er svært lovende for norsk helsetjeneste da tilbudene som er unders $\varnothing \mathrm{kt}$, i stor grad likner på tilbud vi har i Norge.

\section{QALY}

$\mathrm{QALY}=$ Quality Adjusted Life Years.

QALY betyr kvalitetsjusterte leveår og er et helse økonomisk begrep som benyttes når man vurderer effekten av helsetjenestetiltak og forebyggende virksomhet. Som grunnlag for begrepet kan vi anta at et leveår med plager, sykdom eller funksjonshemninger i ulik grad har redusert kvalitet sammenliknet med et leveår uten tilsvarende problemer. Graden av reduksjon i kvalitet avhenger av problemets art og gis et tallmessig uttrykk.

Kilde: Store medisinske leksikon

\section{Forskning i praksis}

Daglig får sosial- og helsepersonell positive tilbakemeldinger fra pasienter og pårørende som har deltatt i ulike mestringstilbud, som for eksempel lærings- og mestringskurs, individuell opplæring til egenmedisinering, bruk av hjelpemidler eller oppfølging i frisklivssentralen.

For å sikre god kvalitet på tilbud i ulike helsetjenester må vi omsette og ta i bruk ny forskningsbasert kunnskap, ikke bare fra biomedisin, men også forskning som handler om hvordan vi kan tilrettelegge for $\varnothing \mathrm{kt}$ livskvalitet og styrket mestring. Nyere forskning viser at dette kan lønne seg (2).

\section{Vært viktig lenge}


Det er nå over 20 år siden tidligere statsråd Gudmund Hernes og flere andre ildsjeler opprettet landets første lærings- og mestringssenter (LMS) ved Aker sykehus (3). Her var norske helsepolitikere banebrytende. Bakgrunnen for å opprette sentret var nye tanker om brukermedvirkning og betydningen av brukernes erfaringskunnskap når det handler om å leve med sykdom og funksjonsnedsettelser.

Grunntankene som det første lærings- og mestringssentret var bygget på, fikk stor tilslutning både fra helsepolitikere og fagmiljøer. Det var en klar intensjon om at lærings- og mestringssentret skulle være en drivende kraft og en felles arena for samarbeid om informasjon og opplæring, både mellom fagpersoner og brukere samt mellom fagfolk på tvers av fag, avdelinger og nivåer i helsetjenesten. Sentrene skulle dessuten samarbeide tett med sykehusavdelinger, brukerorganisasjoner og kommuner (2).

\section{«Grunntankene som det første lærings- og mestringssentret var bygget på, fikk stor tilslutning både fra helsepolitikere og fagmiljøer.»}

Da de nye helselovene kom i 2001, ble «pasient- og pårørendeopplæring» løftet frem som en av sykehusenes fire kjerneoppgaver (4). Denne eksplisitte formuleringen har hatt stor betydning for satsingen på lærings- og mestringssentre. Etter foretaksreformen i 2002 fremsatte helsemyndighetene krav om at alle helseforetakene skulle ha et lærings- og mestringssenter.

Nasjonal kompetansetjeneste for læring og mestring innen helse ble etablert i år 2000. Den het tidligere Nasjonalt kompetansesenter for læring og mestring ved kronisk sykdom. Tjenesten bidro med utstrakt veiledning og formidling av stimuleringsmidler, noe som resulterte i lærings- og mestringssentre ved alle helseforetak innen få år. I dag har sykehusene spesialiserte tilbud til personer med ulike diagnoser, både store og små (2). 


\section{Samhandlingsreformen}

I forbindelse med samhandlingsreformen har

kommunene fått et utvidet ansvar for lokal lærings- og

mestringsvirksomhet. Lov om kommunale helse- og

omsorgstjenester fra 2011 sier blant annet i $\S 1$ at

lovens formål er å «tilrettelegge for mestring av

sykdom, skade, lidelse og nedsatt funksjonsevne», og

«å sikre nødvendig opplæring av pasient, bruker og

pårørende» (5).

\section{«Hovedaktiviteten i dag skjer i individuelle møter, integrert i fagavdelingenes $\emptyset$ vrige praksis.»}

Hovedaktiviteten i dag skjer i individuelle møter, integrert i fagavdelingenes $\varnothing$ vrige praksis. Kommunene er i ferd med å bygge opp en lærings- og mestringsvirksomhet i grupper som kan være knyttet til egne lærings- og mestringssentre, frisklivssentraler, frisklivs- og mestringssentre, lokalmedisinske tjenester, brukerorganisasjoner, helsehus og ulike fagavdelinger (5).

\section{Mestring og helseøkonomi}

For å finne ut om et tilbud virker etter hensikten, må vi måle effekten. Det er metodisk svært utfordrende og kostnadskrevende å måle effekter over tid av tilbud med mål om læring og mestring.

I medisin og helseforskning er det lang tradisjon for effektforskning, der randomiserte, kontrollerte studier (RCT-er, Randomised Controlled Trial) anses som «gullstandarden». En systematisk gjennomgang av flere RCT-studier vil gi den mest solide dokumentasjonen på effekt. Slike gjennomganger omtales som metastudier eller systematic reviews.

Sørlandet sykehus, Universitetet i Bergen og forskningssjef Frode Gallefoss var tidlig ute her i Norge med å foreta en effektstudie av lærings- og mestringstilbud for personer med astma og kols (6). Resultatene viste at tilbudene var svært kostnadseffektive. 
Til tross for at denne studien ble gjennomført i perioden 2001 til 2003, refererer internasjonale tidsskrifter fortsatt hyppig til den. Dessverre finnes det ikke videre forskning på helse økonomiske effekter av tilbud i Norge etter den tid. Derfor har vi valgt å oppsummere den internasjonale forskningen på helseøkonomi knyttet til deltakelse i tilbud med mål om læring og mestring.

\section{Kunnskapsoppsummering}

For å finne ut hvilke effekter eller nytteverdi det har å delta i tilbud med mål om læring og mestring har vi inkludert totalt 56 forskningsartikler fra en rekke land. Fordi det er gjort lite forskning på helseøkonomi, også internasjonalt, har vi samlet og gjennomgått resultatene fra samtlige studier som har kommet opp i systematiske litteraturs $\varnothing \mathrm{k}$ helt tilbake til år 2000.

Det viste seg raskt at det var så stor variasjon i typer tilbud og hva som er unders $\varnothing \mathrm{kt}$, at det ikke var mulig å gjennomføre denne studien som en systematic review, der kun studier som har fulgt gullstandarden, ville blitt inkludert. Vi har derfor samlet og systematisert resultatene ved hjelp av scoping review som metode.

Når vi bruker scoping review, er oppmerksomheten gjerne rettet mer mot nytteverdi og mindre mot metodevurdering $(8,9)$. Vi ekskluderte derfor ingen studier med bakgrunn i metode. Overordnet kan vi likevel si at de inkluderte studiene er av god metodekvalitet, men ikke alle oppfyller kravene til et RCT-design.

De fleste studiene hadde målt endringer fra 6 til 24 måneder etter endt tilbud. Noen studier hadde målt endringer over enda lengre tid. Resultatene fra vår gjennomgang er publisert i det anerkjente tidsskriftet Patient Education and Counseling (1). 


\section{Inkluderte studier}

De studiene vi inkluderte, har unders $\varnothing \mathrm{kt}$

helseøkonomisk utbytte fra deltakelse i mange ulike typer tilbud, både individuelle og/eller gruppebaserte, diagnosespesifikke (54/56) og på tvers av diagnoser (2/56), både i primær- og spesialisthelsetjenesten. Det var diagnosespesifikke tilbud for dem som lever med kols, astma, kronisk smerte, hjertesykdom og diabetes som var blitt mest unders $\varnothing \mathrm{kt}$.

I 26 av 56 studier ble tilbudene drevet av tverrfaglige team. I resten av studiene var det én fagperson som drev tilbudene, som oftest en spesialsykepleier eller fysioterapeut. I seks studier var brukerrepresentanter med på å planlegge og gjennomføre tilbudet. Det var stor variasjon i antall sesjoner, struktur og lengde på tilbudene.

\section{Evaluere helseøkonomien}

Studiene som unders $\varnothing$ ker helse $\varnothing$ konomi, samler gjerne data fra deltakerne selv, pårørende, diverse helseregistre, journaler på sykehus, fastlegen og forsikringsselskaper. Det varierer hvordan studiene kategoriserer og beskriver kostnader og utgifter. Gullstandarden er å analysere helseøkonomiske studier i det samfunnsmessige perspektivet, kalt societal perspective, med alle direkte og indirekte kostnader inkludert.

Det er mest vanlig å presentere resultater på forbruk av helsetjenester som sykehusinnlegger, med antall og gjennomsnittlig liggetid, samt antall konsultasjoner i poliklinikk og hos fastlegen. Noen studier hadde også unders $\varnothing \mathrm{kt}$ antall sykedager, og mange studier rapporterte om kvalitetsjusterte leveår.

\section{Viktige tilbud}


Tilbud med mål om læring og mestring er ikke bare god helseøkonomi. Det kan også være svært nyttig for den enkelte som deltar (9). Forskningsresultatene for helse økonomisk utbytte var sammenfallende på tvers av tilbudene som ble unders $\varnothing$ kt. Det kan bety at ikke alle skal ha like tilbud, men at alle skal få tilbud og kunnskap basert på behov.

I dag er det stort sett tilfeldig hvem som får tilbud med mål om læring og mestring. De som lever med helseutfordringer, trenger kunnskap for å mestre situasjonen sin og har behov for møter med helsepersonell som har formidlingskompetanse. Det er viktig med stor variasjon i typer tilbud basert på både individuelle behov, men også på diagnose og bosted siden behovene vil variere.

\section{«I dag er det stort sett tilfeldig hvem som får tilbud med mål om læring og mestring.»}

Fra forskningen vet vi nå en god del om at lærings- og mestringstilbud, i varierende former, er gode tiltak for å sikre en mer likeverdig helsetjeneste. Med dette som bakteppe er det all grunn til å undersøke kvaliteten på dagens lærings- og mestringstilbud og sette klare standarder for arbeidet med å sikre pasienter likeverdige helsetjenester og god mestring også på dette viktige området. Det er derfor essensielt at denne kunnskapen integreres i helsepolitiske føringer og prioriteringer i årene fremover.

\section{Høies ambisjoner}

Det er ikke bare Gudmund Hernes som var opptatt av brukermedvirkning, læring og mestring. Også i dag har vi en helseminister som er opptatt av å skape «pasientens helsetjeneste». Bent Høie sier at «helse handler om mer enn å redde livet. Det handler om å mestre det også» (10). Hans egen definisjon på helse er «å mestre de fysiske eller psykiske belastningene som kropp og sjel utsettes for» (10). 


\section{«Også i dag har vi en helseminister som er opptatt av å skape 'pasientens helsetjeneste'.»}

Med mål om kvalitet og likeverdige helsetjenester er det viktig å styrke arbeidet med å tilrettelegge for læring og mestring hos brukere, pasienter og pårørende. Hvis vi går bak festtaler og visjoner, er det imidlertid fortsatt langt igjen før denne virksomheten har samme status, posisjon og omfang som helse- og omsorgstjenestens andre hovedoppgaver.

\section{Referanser}

1. Stenberg U, Haaland-Overby M, Fredriksen K, Westermann KF, Kvisvik T. Health economic evaluations of patient education interventions. A scoping review of the literature. Patient Educ Couns. 2018;101(6):1006-35.

2. Lerdal AF, Fagermoen MS. Læring og mestring et helsefremmende perspektiv i praksis og forskning. Oslo: Gyldendal Akademisk; 2011.

3. Lov 2. juli $1999 \mathrm{nr} .61 \mathrm{om}$ spesialisthelsetjenesten. Tilgjengelig fra: https://lovdata.no/dokument/NL/lov/1999-07-02-61 (nedlastet 12.02.2018).

4. Lov 24. juni $2011 \mathrm{nr} .30$ om kommunale helse- og omsorgstjenester. Tilgjengelig fra: https://lovdata.no/dokument/NL/lov/2011-06-24-30 (nedlastet 12.02.2018).

5. Helsedirektoratet. Veileder om rehabilitering, habilitering, individuell plan og koordinator. Oslo: Helsedirektoratet; 2015. IS-2651. Tilgjengelig fra: https://helsedirektoratet.no/retningslinjer/rehabiliterin g-habilitering-individuell-plan-og-koordinator (nedlastet 12.02.2018).

6. Gallefoss F. The effects of patient education in asthma and COPD. (Doktoravhandling.) Bergen: Universitetet i Bergen, Det medisinske fakultet; 2001. 
7. Arksey H, O’Malley L. Scoping studies: Towards a methodological framework. Int J Soc Res Methodol. 2005;8(1):19-32.

8. Levac D, Colquhoun H, O'Brien KK. Scoping studies: advancing the methodology. Implementation science : Implementation Science. 2010;5:69.

9. Stenberg U, Haaland-Overby M, Fredriksen K, Westermann KF, Kvisvik T. A scoping review of the literature on benefits and challenges of participating in patient education programs aimed at promoting selfmanagement for people living with chronic illness. Patient Educ Couns. 2016;99(11):1759-71.

10. Høie B. Mestringens mestre. Helse- og omsorgsministerens kronikk i VG. Oslo: Helse- og omsorgsdepartementet; 2014. Tilgjengelig fra: https://www.regjeringen.no/no/aktuelt/mestringens mestre/id749727/ (nedlastet 01.02.2018). 